\title{
The Character of the Vocational Teacher's Work
}

\author{
Siti Mariah \\ Sarjanawiyata Tamansiswa University \\ Yogyakarta, Indonesia \\ siti.mariah@ustjogja.ac.id
}

\begin{abstract}
The purpose of this research is to find out the work character of vocational teacher in terms of: work commitment, work ethic, work appreciation, work culture, and work motivation. The research method used a survey in 5 cities and regencies in Yogyakarta. Data completion techniques used questionnaires through conceptual, theoretical, and empirical studies with Delphi techniques. The study population is all teachers of SMK in Yogyakarta with sampling using Two Stage Cluster Sampling and judgment sampling, namely Master Department of Mechanical Engineering, Automotive, Industry, Culinary and Clothing in accredited SMK A. Data analysis using descriptive technique with Percentage calculation. The results showed that the work character of vocational teachers is in the high category. Interesting findings from this study still exists between the expectations and character of teacher work character today. Recommendations for further research foster a model of character building for candidate vocational teachers to have a work ethic and work motivation, responsible, courageous and risk-taking, creative, productive, and competitive.
\end{abstract}

\section{Keywords- teacher, vocational, work character}

\section{INTRODUCTION}

The National Long-term Development Plan 2005-2025 puts character education as its first mission in order to realize the vision of national development. Character development has not fully devoted a comprehensive attention to efforts to achieve national education goals. It is shown by various news about education problem in Indonesia, such as: selling case of exam key, cheating contest, plagiarism, student brawl, criminal case done by student, even teacher dishonesty because collecting data / false evidence to complete portfolio in fulfilling requirement Teacher certification (Kompas, 2007a, 2007b, 2007c, 2007d, 2007e).

Vocational High School (SMK) SMK as a sub system in the national education system is designed to bridge a person to the world of work, and aims to prepare graduates to be productive individuals, able to work as a workforce, and have the readiness to face work competition (MoNE, 2004). However, education and training in SMK still leave the content of the basic values of character development and work attitude [1]. Further explained that the school world is accustomed to relax, not to know delivery time, and the school world is less familiar with the sense of quality because the work is not related to the market. These habits and behaviors ultimately shape the attitudes of SMK graduates who underestimate quality, likes to graduate, not confident, undisciplined, and irresponsible. Industry and trade competition in general will always refer to price, quality, design, delivery time, marketing and service. The implication of vocational school students should be educated by teachers who have superior and professional work character [2].

The importance of work character becomes the thing that determines the success of a person in the work. The character strengths are positively related to university students' psychological well-being [3]. The relation between character strengths and psychological well-being can have an important effect on students' academic performance [4].

Each field of work requires a certain working character that supports the implementation of its work. Working competence is composed of: routine expertise, resourcefulness (related to creativity?), functional literacies (digital literacy!), craftsmanship, business-like attitudes (economic and social aspects), wider skills for growth (inquisitive, resilient, indepent learner - also creativity) [5]. The character of work is in the domain of personal and social competence. In this study manifested by work commitment, work motivation, work ethic, work appreciation, and work culture.

Each educational institution needs to establish in advance the type of work character that needs to be developed. Exploration of research results and input from experts can be used as a consideration to choose which work character needs to be developed. The research formulation is to analyze "profession character profile of vocational teacher", hence the purpose of this research, that is how work commitment profile, work ethic, work appreciation, work motivation, and work culture of vocational teacher. The results of this study are expected to contribute significantly to improving the quality of Vocational Teachers candidates, especially the character of its work so as to support the realization of graduates of vocational schools are superior.

\section{RESEARCH METHODS}

The research method used is a descriptive quantitative survey research that aims to determine the character of teachers Vocational teachers in SMK. The teacher work character that is reviewed is on the aspect of work commitment, work ethic, work appreciation, work motivation, and work culture owned by vocational teachers (SMK) spread in Yogyakarta.

Data collection techniques used questionnaires to capture vocational teacher work character data developed based on instrument grid. To generate the importance of vocational teacher work character indicator, Delphi technique is used through conceptual, theoretical, and empirical studies in the field by vocational education experts and practitioners based 
on content, constructs and languages with percentages of agreements [6]. Percentage of expert level of understanding on Vocational Teacher's Vocational Teacher performance indicator on average above $90 \%$, as follows:

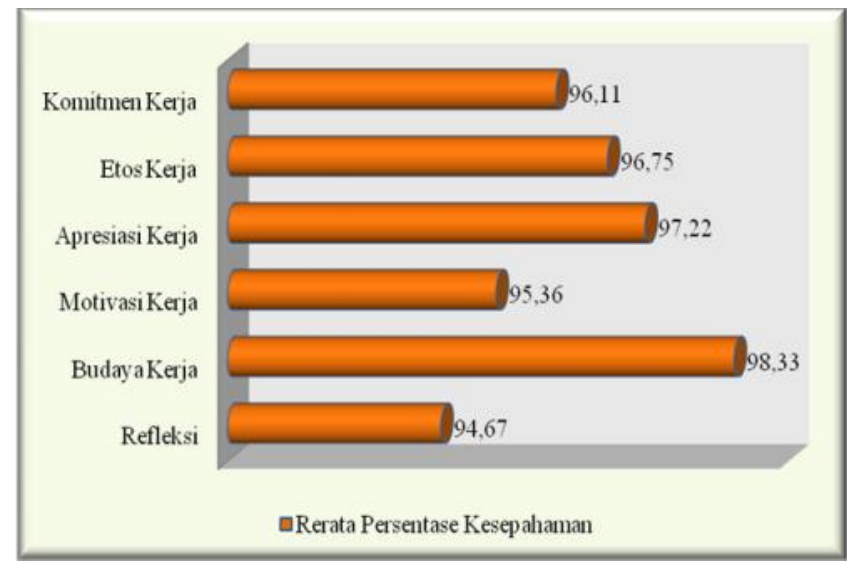

Figure 1. Percentage of expert level of understanding on indicators of Vocational Teacher's work character

The population used as the object of this study is all teachers of SMK in Yogyakarta with sampling using Two Stage Cluster Sampling (TSCS) and judment sampling is to choose something or someone to sample because they have "information rich". The sample subjects of this research are teachers of SMK Teknologi dan Rekayasa Department of Mechanical Engineering, Automotive, and Industry; As well as SMK Tourism in the Department of Culinary and Clothing. SMK sample used in this study is determined by the value of accreditation A. Determination of location and place of research based on the assumption that the clumps Teknologi dan Rekayasa in SMK has the same characteristics that is the competency standards of graduates to meet the workforce in the manufacturing industry, so it takes teachers who have Industry-based work characteristics. While the vocational school with accreditation $\mathrm{A}$ is assumed to have teachers with good working character.

Data analysis technique used in this research is quantitative descriptive analysis with percentage, the data obtained is quantitative in the form of numbers. The calculated results obtained are summed and the results are compared with the expected number of scores so that the percentage is then inserted with the standard value used to give the meaning of the result of the count through the percentage.

The data obtained from each variable is tabulated by using relative frequency distribution table, then done scoring on each alternative answers in accordance with the criteria have been determined on the likert scale. Description of research data includes a description of the general description of each indicator of work character. Data analysis technique used in this research is quantitative descriptive analysis with percentage.

The criterion of percentage of expert agreement in assessing the instrument used the criterion of assessment proposed [7], in Table 1 below:
TABLE 1. Percentage Rating Criteria

\begin{tabular}{c|c|c} 
& TABLE 1 . Percentage Rating Criteria \\
\hline \multirow{2}{*}{ Angka } & Interval skor rata-rata & Kriteria \\
\hline 4 & $90,0<$ skor $\leq 100$ & Very good \\
3 & $80,0<$ skor $\leq 89,0$ & Good \\
2 & $70,0<$ skor $\leq 79,0$ & Enough \\
1 & $60,0<$ skor $\leq 69,0$ & Less \\
0 & $0,00<$ skor $<59,0$ & Very Less \\
\hline
\end{tabular}

\section{RESULTS AND DISCUSSION}

\section{A. Character of Vocational Teacher Work}

Description of research data is the presentation of research results in the field about the character profiles of vocational teachers in SMK in terms of work ethic aspect, work commitment, work appreciation, work motivation, and work culture proposed as follows:

\section{Vocational Teacher Working Commitment}

Commitment in the workplace has evolved to encompass a broad range of types, such as engagement, attachment, commitment and involvement [8]. Numerous studies on commitment have been undertaken in the disciplines of behavioural, attitudinal and motivational sciences, within three broad research streams, through sociological, industrial and organisational psychology and health psychology [9]; all emphasise the importance of commitment in the workplace. It has been the subject of excessive research and empirical attention, as a consequence and an antecedent of other workrelated variables [8] and has been linked to workplace outcomes [10].

The results showed the work commitment of SMK Teachers seen in the following Figure 2:

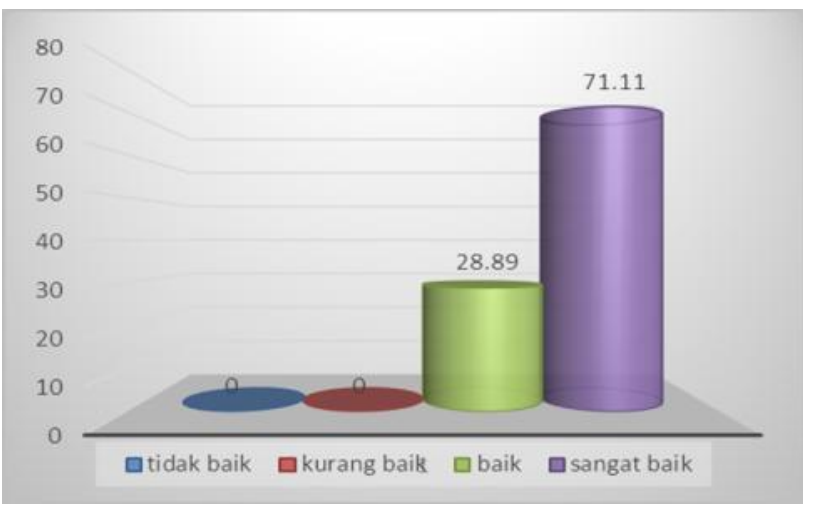

Figure 2. Vocational Teacher Working Commitment

Profile of work commitment of vocational teachers (SMK) as shown in Figure 1, very good $(70,11 \%)$ and good $(28,89 \%)$. It shows that the commitment of vocational teachers in SMK has been very good. Vocational teachers in SMK have excellent loyalty and sincerity in working. So work commitments must be built, kept to exist in the heart of every vocational teacher. Without commitment it is difficult to expect active and in-depth participation from human resources. Employees with a high level of commitment tend to make greater effort to perform and invest their resources in the organisation [11]. 


\section{Teacher Vocational Work ethic}

In the formulation of Sinamo [12] the work ethic is a set of positive behaviors rooted in fundamental beliefs accompanied by total commitment to the integral work paradigm. According to him, if a person, an organization, or a community embraces a working paradigm, believes and is committed to the work paradigm, it will give rise to their unique work attitude and behavior that will be the work ethic and culture. The work ethic is the foundation of true and authentic success [12]. Through the above understanding both etymologically and practically can be concluded that the work ethic is a set of attitudes or fundamental views held by a group of people to assess work as a positive thing for improving the quality of life that affects the behavior of his work. The profile of the work ethic of vocational teachers in SMK is illustrated in the following figure 3 :

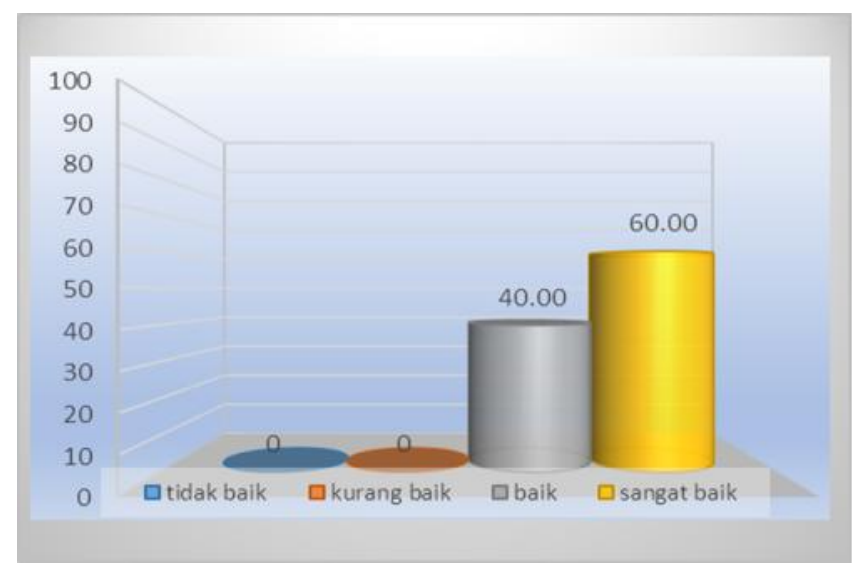

Figure 3. Teacher Vocational Work ethic

Figure 3 above shows that the work ethic of SMK Teachers is in very good category (60\%) and good (40\%), it shows that the work ethic of Vocational High School teacher is now good. Work ethics is viewed from the practical side of the attitude that leads to appreciation of work and efforts to increase productivity. Vocational student candidates are not only educated to have knowledge and skills in a particular area of expertise, but have a concern for the quality standards of work, timeliness in doing a task, the accuracy of the standard size, and the service. Thus, the work ethic should be owned by vocational teachers whose main purpose is to prepare students for work.

\section{Vocational Teacher Work Motivation}

Motivation is defined as the condition or energy that moves the targeted or targeted employees to achieve the company's goals. That as a motive (motive) which means encouragement, cause or reason someone to do something [13]. Of these two definitions, motivation can be summed up as energy, impetus, or cause someone to do something. In relation to work, then the work motivation is energy, thrust, or cause someone to work. The result of research shows that the work motivation of SMK teachers has been very good 75,56\% and good $24,44 \%$. Psychologically, the passion or spirit of a person in carrying out his work is strongly influenced by the motivation of work that encourages him.

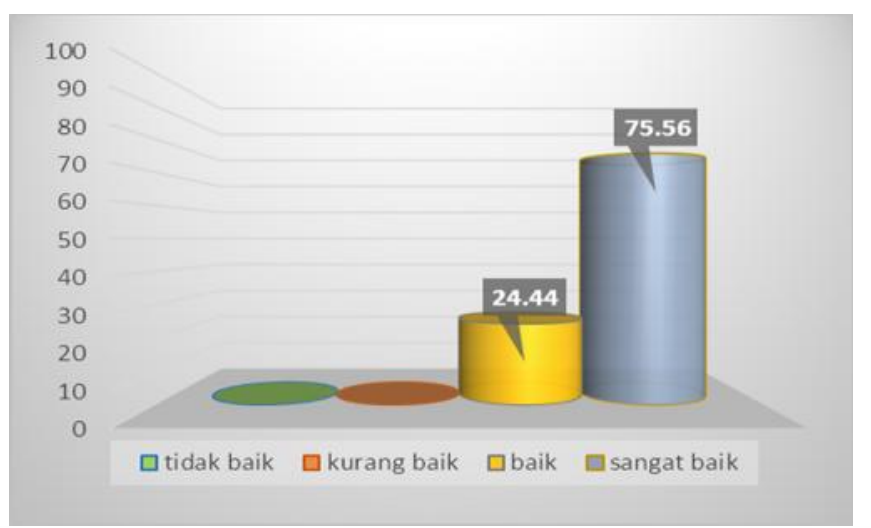

Figure 4. Vocational Teacher Work Motivation

To motivate one's personnel and encourage them to work at their full potential, therefore, it is not only important to decrease job demands, but also-and perhaps most important-to provide a positive and resource-filled work environment [14].

\section{The Vocational Teacher Work Appreciation}

When individuals feel appreciated and valued for their contributions in the workplace, good results follow, including increased employee engagement, less staff turnover, higher customer satisfaction ratings and the organization grows in its sense of purpose. The Motivating by Appreciation Inventory and Appreciation at Work Training are unique tools that help organizations grow in employee appreciation [15].

In relation to work, the word appreciation implies understanding, enjoying and appreciating the field of work as a meaningful activity for himself and others. A person will not be able to do his job well before understanding and also feel what is contained in his work. The work teacher's appreciation profile of SMK appears on the following histogram images:

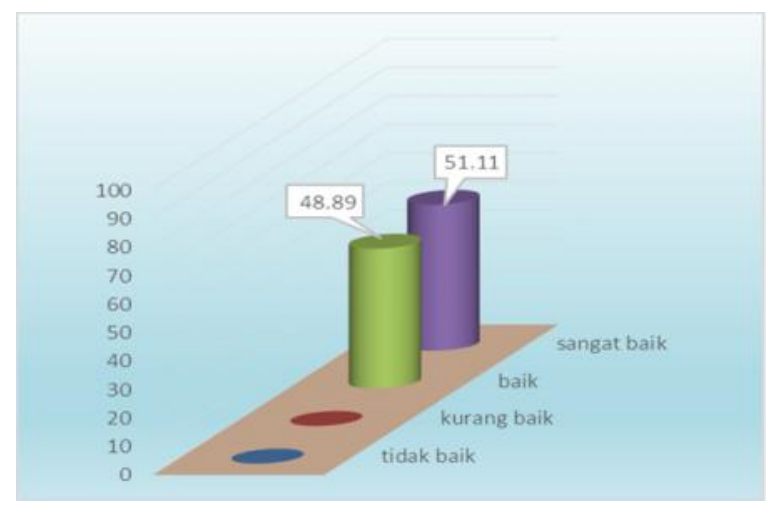

Figure. 5 Appreciation of Vocational Teacher work

Figure 5, shows that the teacher work appreciation profile of SMK teachers in good category $(48.89 \%)$ and very good $(51.11 \%)$, it shows that SMK teachers have very good work appreciation to their work as teachers who educate and prepare participants Educated to work and able to develop himself. But the appreciation of work takes time to dive it, meaning, 
aware of its function in every work activity, so it should be fostered and developed in prospective vocational teachers in this case on students majoring in technology and vocational education.

\section{Vocational Teacher Work Culture in SMK}

The work culture is the values adopted by a person or group of people who have become a habit in their working life and even in their wider life. Therefore, the work culture can be seen from the attitude and behavior in doing a job, face or solve a problem in the work. Profile of SMK Teacher's work culture can be seen in the following histogram images:

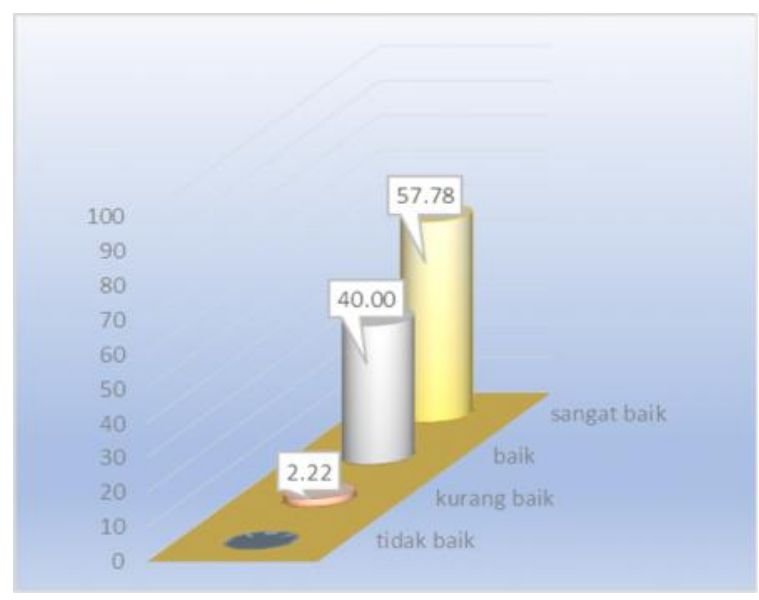

Figure 6. Vocational Teacher Work Culture in SMK

The work culture of SMK teachers generally shows good category $(40 \%)$ and very good $(57,78 \%)$, although there are still less good (2,22\%). According to Magnis (1993) the more necessary to produce an ethical person is habituation. Behavior that continues to be repeated, increasingly deeply embedded, becomes a habit, then becomes the nature and becomes part of the personality.

The uniqueness of the learning process in vocational schools that emphasizes more on the aspects of sharpening skills or hard skills to achieve the level of competence in accordance with the purpose of learning. The intensity of continuous practice learning done in every semester, is a strategic container to integrate the development of work character through work habituation. Intensify the stage of doing continuously will occur habituation in doing a job.

The characteristics of low work culture, among others: (1) complaining, demanding, selfish; (2) work at will, lack of care; (3) often delaying work, manipulative; (4) lazy, bad discipline, low stamina work; (5) minimal service, a sense of belonging thin, less work passion; (6) stuck in a routine, resisted change, was less creative; (7) work carelessly, quickly satisfied; (8) the soul serves low, feels great, and arrogant [16] - Teachers who possess these work culture traits will not be able to adapt and teach work culture to students in vocational schools, where the demands of work quality and timeliness, and good cooperation will greatly determine the survival industry in the global economic arena.

\section{B. Character Gap of Vocational Teacher Work in SMK}

The results of the survey on Vocational Teachers in Yogyakarta taken samples on SMK teachers graduates JPTK Tourism and Technology with accreditation category A. Obtained data of hope and reality of work character of SMK Teachers viewed from aspects of work commitment, work ethic, work appreciation, work culture, and work motivation.

TABLE 2. Expectations and reality of work character of Vocational Teachers

\begin{tabular}{lccc}
\hline Attribute & $\begin{array}{c}\text { Average score } \\
\text { Expectation of } \\
\text { teacher work } \\
\text { character }\end{array}$ & $\begin{array}{c}\text { Mean score of } \\
\text { teacher work } \\
\text { character at } \\
\text { present }\end{array}$ & Gap \\
\hline $\begin{array}{l}\text { Work } \\
\text { commitment }\end{array}$ & 3.59 & 3.37 & 0.22 \\
\hline $\begin{array}{l}\text { Work ethic } \\
\text { Appreciatio }\end{array}$ & 3.79 & 3.34 & 0.45 \\
\hline $\begin{array}{l}\text { Work work } \\
\text { Culture }\end{array}$ & 3.8 & 3.54 & 0.26 \\
\hline $\begin{array}{l}\text { Work } \\
\text { motivation }\end{array}$ & 3.59 & 3.38 & 0.37 \\
\hline & 3.70 & 3.14 & 0.45 \\
\hline
\end{tabular}

Table. 2 shows that there is a gap between expectations and reality of the current working character of SMK teachers by 0.35 . The highest gap (0.45) in the attributes of work ethic and work motivation, it is assumed that the work character of vocational teacher candidate students still need to be improved to have a good work ethic and work motivation such as; Responsible, courageous and risk-taking, doing something better than others, doing things as well as possible, and having high work motivation such as; Vibrant, creative, productive, and competitive. The next gap is the work culture $(0.37)$, appreciation (0.26), and the lowest gap is the work commitment of (0.22).

Based on the data of the research, it can be concluded that the character gap of vocational teachers teachers of JPTK graduates is caused by the competence of vocational school teachers not only have pedagogical, personality, professional and social competence. Vocational teachers in productive programs have specific professional characteristics and requirements, namely: 1). Have sufficient practical skills in all productive subject areas (subjects); 2). Able to organize learning (training) that is relevant to the competencies required by the world of work; 3). Able to design learning (training) in schools and in business or industry. In addition, it has a personal competence that is specific to the character of work, namely: 1) have a commitment to the learning tasks in preparing students able to work and develop themselves in the field of expertise; 2) having a work ethic in accordance with the system of expertise; 3) has an appreciation for the field of work, both as a vocational teacher and on the specifications of his area of expertise; 4) have a high work motivation to develop students' potential to be more creative, innovative, and competitive; And 5) have a work culture that can be used as a model for students in doing a task / job. Thus, vocational school teachers are required to have specific job characteristics in accordance with their areas of expertise. 


\section{CONCLUSION}

Character of teacher work Vocational viewed from work commitment, work ethic, work appreciation, work motivation, and culture show good and very good, but there is still a gap between expectation and reality of Vocational teacher work character of 0.35 , with the highest gap value at Attributes of work ethic and work motivation.

\section{Limitations and Future Directions}

Limitations of this study. First, the relatively small research population response rate and its distinctive features make it difficult to generalize findings. However, it is known that certain jobs have not received proper attention because of the relatively small objective resistance to response rates. Despite these difficulties, research was done to overcome the problem and to try to bridge the abyss of somewhat abandoned occupation. Secondly, this study is based on self-reported data and thus can bring the common method variance bias.

Validation actions can be used to reduce the likelihood of bias in common method variance. Finally, using samples and collecting data from various Schools (SMK), enables us to obtain better external validity and improve the generality of results.

Several suggestions for further research, namely: it is important to validate the relationship between work commitment, work culture, work ethic and work motivation, and further efforts should be invested in building validated work character models. Additional research should explore the relationship between variables. Finally, more work needs to be done to test the working character indicator.

\section{REFERENCES}

[1] Djojonegoro, Wardiman, "Pengembangan sumber daya manusia melalui sekolah menengah kejuruan (SMK)", Jakarta: PT.Jayakarta Agung offset, 1998, p.70

[2] Siti Mariah, "Kesenjangan soft skills lulusan SMK dengan harapan tenaga kerja di Industri”, Jurnal Inovasi dan Perekayasa Pendidikan volume 3 No. 1, 2010, pp.379-400
[3] Gustems, Josep, \& Caterina Calderon. "Character Strengths and Psychological Wellbeing among Students of Teacher Education." International Journal of Educational Psychology [Online], 3.3 (2014): 265-286. Web. 11 Aug. 2017

[4] Brookfield, Stephen D. The skillful teacher: On technique, trust, and responsiveness in the classroom. John Wiley \& Sons, 2015.

[5] Lucas, B., Spencer, E., \& Claxton, G. (2012). How to teach vocational education: A theory of vocational pedagogy. Centre for Real-World Learning, University of Winchester, (Dec), 133. Retrieved from http://www.skillsdevelopment.org/PDF/How-to-teach-vocationaleducation.pdf

[6] Grinnell, Richard M, "Social research and evaluation", Illinois: F.E. Peacock Publisher, Inc, 1988, p.160

[7] Sax, G, "Principle of educational and psychological measurement and evaluation" California: Wadsworth, Inc 1980,p.570

[8] Martin, A., \& Roodt, G. (2008). Perceptions of organisational commitment, job satisfaction and turnover intentions in a post-merger South African tertiary institution. South African Journal of Industrial Psychology, 34, 23-31. [ Links ]

[9] Roodt, G. (2004). Concept redundancy and contamination in employee commitment research: Current problems and future directions. SA Journal of Industrial Psychology, 30(1), 8290. http://dx.doi.org/10.4102/sajip.v30i1.135 [ Links ]

[10] Field, L. K., \& Buitendach, J. H. (2011). Happiness, work engagement and organisational commitment of support staff at a tertiary education institution in South Africa. South African Journal of Industrial Psychology, 37, 68-77. [ Links ]

[11] Saal, F.E., \& Knight, P.A. (1987). Industrial-organizational psychology: Science and practice. Pacific Grove, CA: Brooks/Cole. [ Links ]

[12] Sinamo, Jansen, "Delapan etos kerja profesional", Jakarta: Institut Mahardika, 2005, p.1.

[13] Nawawi, "Sumber daya manusia untuk bisnis yang kompetitif. Jakarta: Prenhalindo, 2001, p.351.

[14] De Cooman, R., Stynen, D., Van den Broeck, A., Sels, L., \& De Witte, H. (2013). How job characteristics relate to need satisfaction and autonomous motivation: Implications for work effort. Journal of Applied Social Psychology, 43(6), 1342-1352.

[15] Paul White, (2016). Appreciation at Work training and the Motivating by Appreciation Inventory: development and validity, Strategic HR Review, Vol. 15 Issue: 1, pp.20-21, https://doi.org/ 10.1108/SHR11-2015-0090

[16] Toto Tasmara, "Membudayakan etos kerja yang Islami". Jakarta: Gema Insani Press, 2002, pp.13-14. 